\title{
Experimental Behaviour of Fiber Reinforced Reactive Powder Concrete
}

\author{
Arunkumar K, Muthukannan M, Suresh Kumar A
}

\begin{abstract}
In this paper various mix proportions of Reactive Powder Concretes were formulated using ordinary Portland cement, Fly ash, Micro silica, Silica Fume, Quartz powder etc and these concretes were subjected to strength test. The best mix was selected for further in depth study with fibers like Sisal fiber, Coir fiber, Hair fiber and Polypropylene fiber mixed Reactive Powder Concrete and the various tests have been performed Cube Compressive strength, Cylinder Compressive strength, Flexural strength, Split Tensile strength, Shear test, Water absorption, Sorptivity and Chloride diffusion etc. As a result, fiber incorporated concrete shows increasing Flexural strength, splitting tensile strength, and shear strength up to $30 \%$ as compared to control RPC and gives minimal decrease in compressive strength by the addition of fibers. These characteristics make it as a promising material for casting non structural elements such as pressure pipes, flooring tiles, Partition panels, door and window frames. It can also be used as repair materials.
\end{abstract}

Keywords: Reactive Powder Concrete, Natural Fibers, Silica Fume, Quartz Powder.

\section{INTRODUCTION}

The most popular engineering material is concrete. Concrete is generally considered a proper construction material for many civil and military applications. It can be strong and produced to be durable. It can be placed in many shapes and is economical. Since it is much stronger in compression weak in tension, concrete is primarily used for its compressive strength. Therefore, intensive research efforts have been devoted to the improvement of the compressive strength of concrete (O'Neil et al.2001)1. Every day the quality of concrete is improving, to achieve better characteristics, lower prices and to be environmentally acceptable. The employment of removal of the coarse aggregate is being developed as Reactive Powder Concrete (RPC). It was first developed in the early 1990's by Bouygues laboratory in France. Then, in July 1997, it was first employed for the building Sherbrooke Bridge in Canada. Reactive Powder Concrete (RPC) is a developing composite materials that will allow the concrete industry to optimize the material use, generate economic benefits and build structures that are

Revised Manuscript Received on December 5, 2019

* Correspondence Author

Arunkumar K*, Department of Civil Engineering, Kalasalingam Academy of Research and Education, Tamil Nadu, India. Email: arunapcivil@gmail.com

Muthukannan M, Department of Civil Engineering, Kalasalingam Academy of Research and Education, Tamil Nadu, India. Email: civilkannan@gmail.com

Suresh Kumar A, Department of Civil Engineering, Kalasalingam Academy of Research and Education, Tamil Nadu, India. Email: sureshalmighty@gmail.com strong, durable and sensitive to environment. RPC is an ultra high strength, improved micro structural composite material with advanced mechanical and physical properties. RPC has compressive strength between 200-800 MPa, modulus of rupture between 25-150 MPa, fracture energies (proportional to the area underneath the behavior curves of equivalent bending stress and deflection) of about 30,000 J/m2 and volume weights of $2500-3000 \mathrm{Kg} / \mathrm{m} 3$ (Richard and Cheyrezy 1994). RPCs invariably have young's modulus values exceeding $50 \mathrm{GPa}$, which can go as high as $75 \mathrm{GPa}$. In the latter case we observe that the global modulus for the paste and aggregate is slightly higher than that for the silica aggregate. Thus the effect of mechanical heterogeneity has been totally removed, and even reversed (Richard and Cheyrezy 1995).RPC is a fiber reinforced, super plasticized, silica fume-cement mixture with very low water-cement ratio (w/c) characterized by the presence of very fine quartz sand instead of ordinary aggregate. In fact, it is not a concrete because there is no coarse aggregate in the cement mixture. The absence of coarse aggregate was considered by the inventors to be a key-aspect for the microstructure and the performance of the RPC in order to reduce the heterogeneity between the cement matrix and the aggregate. RPC is composed of more compact and arranged hydrates. The hydration process in RPC is brought to a more extensive and definite level. It consists of a special concrete where its microstructure is optimized by precise gradation of all particles in the mix to yield maximum density. It uses extensively the pozzolanic properties of highly refined silica fume and optimization of the Portland cement chemistry to produce the higher strength hydrates (Dowd 2000)4. By introducing fine steel fibers, RPC can achieve remarkable flexural strength up to $50 \mathrm{MPa}$, tensile and bending strength, its impact resistance, and its toughness. The material exhibits high ductility with typical values for energy absorption approaching those reserved for metals (O’Neil and Dowd 1995)5. RPC also has superb durability parameters such as abrasion resistance and reduced chloride permeability. These durability enhancements decrease maintenance costs and lengthen the service life of a structure. RPC is a material whose potential is yet to be identified. It is therefore expected to be used to containment structures of nuclear power plants and protect military facilities.

\section{MATERIALS USED}

Following are the materials used for the present investigation of Fiber Reinforced Reactive Powder Concrete.

\section{A. Cement}

The cement used for this study is ordinary Portland 
cement (OPC) of 43-grade "Dalmia Brand".

\section{B. Sand}

The sand is of river sand screened and washed to remove all the organic and inorganic compounds that are likely to present in it. Sand has been sieve in $2.36 \mathrm{~mm}$ (passed) and retained in $600 \mu$.

\section{Fly Ash}

The fly ash used for this study was collected from Tuticorin thermal power plant. This falls under the category of low calcium Fly ash. As per ASTM it is classify as the chemical composition are given in Table-I.

Table- I: Physical and chemical properties ordinary Portland cement, Fly Ash and Silica Fume

\begin{tabular}{|l|l|l|l|}
\hline Properties & OPC & Fly Ash & Silica Fume \\
\hline Sp.gravity & 3.10 & 2.21 & 2.20 \\
\hline Fineness & 310 (Blaine) & - & 20,000 \\
\hline Initial setting time & $150($ min) & - & - \\
\hline Final setting time & $260($ min $)$ & - & - \\
\hline $\mathrm{CaO}(\%)$ & 59.30 & 3.00 & 0.20 \\
\hline $\mathrm{SiO}_{2}(\%)$ & 20.9 & 59.0 & 97.67 \\
\hline $\mathrm{Al}_{2} \mathrm{O}_{3}(\%)$ & 6.3 & 33.98 & 0.30 \\
\hline $\mathrm{Fe}_{2} \mathrm{O}_{3}(\%)$ & 4.2 & 7.0 & 0.11 \\
\hline $\left.\mathrm{MgO}_{2} \%\right)$ & 2.5 & 1.3 & 0.20 \\
\hline $\mathrm{SO}_{3}(\%)$ & 2.16 & 0.80 & - \\
\hline $\mathrm{LOI}(\%)$ & 1.90 & 0.50 & 1.2 \\
\hline $\mathrm{C}_{3} \mathrm{~S}(\%)$ & 29.0 & - & - \\
\hline $\mathrm{C}_{2} \mathrm{~S}(\%)$ & - & - & - \\
\hline
\end{tabular}

\section{Silica Fume (SF)}

The silica fume (SF) was purchased from M/s Krishna Conchem Construction chemical suppliers, Bombay. Silica Fume is a industrial waste product obtained from Ferro-silicon industry through electro static precipitators. Its particle size is 100 times smaller than cement grain. The specific surface area is greater than cement. Therefore the silica Fume is used with purpose that it can react with $\mathrm{Ca}(\mathrm{OH}) 2$ to form Calcium Silicate Hydrate $(\mathrm{CSH})$ and also to act as filler.

\section{E. Micro Silica (MS)}

The Micro Silica was purchased from M/s Krishna conchem construction chemical suppliers, Bombay. Micro Silica is slightly higher in particle size and the silicon dioxide cement is greater than $85 \%$.It is slightly gray in color. The effect of micro silica in cementitious mortar is similar to the silica fume.

\section{F. Super Plasticizer (SP)}

CONXL-PCE6650 was used us super plasticizer (SP).It is very dark brown liquid. It was purchased from $\mathrm{M} / \mathrm{s}$ CHEMCON Tecsys., Chennai. The purpose of using the SP is to reduce the water content ratio and enhance the workability of the mix. Normally the dosage is limited to $1.5 \%$ by weight of cement used in the mix.

\section{G. Quartz Powder (QP)}

The quartz powder was purchased from M/s Kumar minerals, karur. It is the white color powder. Its particle size is $<50 \mu$. It is fine powder, used to improve microstructure.

\section{H. Fibers Used \\ 1. Coir Fiber}

It is the raw fiber from coconut skin which was purchased from Singapunari. The process of removal of lignin from the fiber would increase the bonding between the fiber and the concrete. The diameter and the length of the fiber used are 0.1 $\mathrm{mm}$ and $12.5 \mathrm{~mm}$, respectively.

\section{Sisal Fiber}

It is the raw fiber from sisal which was purchased from Dharmapuri. The process of removal of lignin from the fiber would increase the bonding between the fiber and the concrete. The diameter and the length of the fiber used are $0.1 \mathrm{~mm}$ and $12.5 \mathrm{~mm}$, respectively.

\section{Hair Fiber}

It was collected from a nearby barber shop. It was then washed thoroughly with water and air dried. The diameter of the fiber is $300 \mu \mathrm{m}$.

\section{Polypropylene Fiber}

It is a polymeric fiber which was artificially synthesized. The polypropylene fiber was purchased from Reliance industries limited, Mumbai. The diameter and the length of the fiber used are $<300 \mu \mathrm{m}$ and $10 \mathrm{~mm}$, respectively.

\section{Binder for RPC and Preparation}

The binder consists of sodium hydroxide $(\mathrm{NaOH})$, sodium silicate and calcium oxide solution.

- Take 20 gram of $\mathrm{NaOH}$ pellets and dissolve it in $1000 \mathrm{ml}$ of distilled water. Since it is an exothermic reaction heat is evolved and hence it should be dissolved carefully.

- Take $20 \mathrm{ml}$ of sodium silicate solution $\left(\mathrm{Na}_{2} \mathrm{SiO}_{4}\right)$ and stir well.

- Add 2 gram of calcium oxide and mix it with the above solution.

- After the $\mathrm{NaOH}$ solution gets cooled stir $\mathrm{Na}_{2} \mathrm{SiO}_{4}$, $\mathrm{CaO}$ and $\mathrm{NaOH}$ well with stirrer.

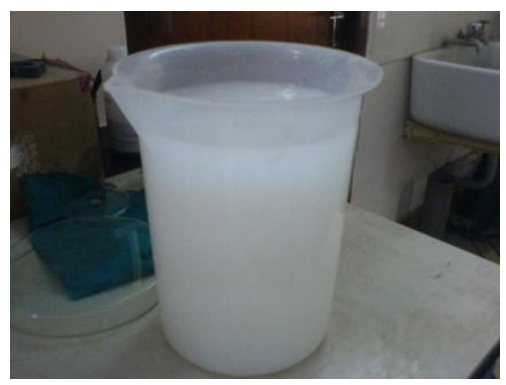

Fig. 1 Binder for RPC

\section{J. Removal of Lignin from fibers}

In natural fibers, Lignin will be present in the surface. So that if fiber is added in concrete the bonding between the fiber and matrix will be decreased due to the lignin present in fibers. Therefore removal of lignin is required in natural fibers. For removing the lignin from fibers $0.5 \mathrm{M}$ of $\mathrm{NaOH}$ in 1 liter is taken and some amount of fibers is stirred in the solution for 75 minutes. 


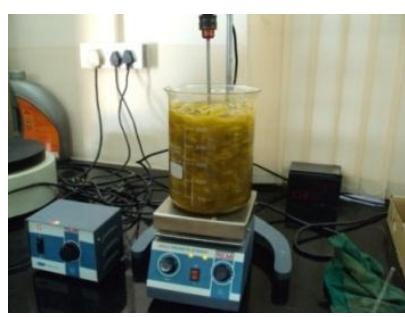

Fig. 2 Removal of Lignin

Table- II:Various trial mixes of the RPC

\begin{tabular}{|l|l|l|l|l|l|l|l|l|}
\hline $\begin{array}{l}\text { Mix } \\
\text { design }\end{array}$ & OPC & Sand & $\begin{array}{l}\text { Fly } \\
\text { ash* }\end{array}$ & MS & SF* & QP* & $\begin{array}{l}\text { SP } \\
\text { \% }\end{array}$ & w/c \\
\hline R1 & 1 & 1.25 & 0.2 & - & 0.07 & - & - & 0.45 \\
\hline R2 & 1 & 1.25 & - & 0.2 & 0.07 & - & - & 0.45 \\
\hline R3 & 1 & 1.25 & - & - & 0.07 & 0.2 & - & 0.45 \\
\hline R4 & 1 & 1.25 & 0.1 & 0.1 & - & 0.1 & - & 0.45 \\
\hline R5 & 1 & 1.25 & 0.1 & 0.1 & 0.07 & 0.1 & - & 0.45 \\
\hline R6 & 1 & 1.6 & 0.05 & 0.15 & - & - & - & 0.5 \\
\hline R7 & 1 & 1.6 & 0.05 & 0.15 & - & 0.05 & - & 0.5 \\
\hline R8 & 1 & 1.6 & 0.05 & 0.15 & - & - & 1.5 & 0.35 \\
\hline R9 & 1 & 1.6 & 0.05 & 0.15 & - & 0.05 & 1.5 & 0.35 \\
\hline R10 & 1 & 1.6 & 0.05 & 0.15 & - & - & 1.5 & 0.30 \\
\hline R11 & 1 & 1.6 & 0.05 & 0.15 & - & 0.05 & 1.5 & 0.30 \\
\hline
\end{tabular}

\section{MIX PROPORTION}

The various mix proportion adopted are given in Table-II.

*to mass of cement,

Table- III: Various fiber mixes of the RPC

\begin{tabular}{|l|l|l|l|l|l|l|l|l|l|l|}
\hline $\begin{array}{c}\text { Mix } \\
\text { Design }\end{array}$ & $\begin{array}{l}\mathbf{O} \\
\mathbf{P}\end{array}$ & Sand & FA & MS & $\begin{array}{c}\text { SP } \\
\mathbf{\%}\end{array}$ & $\begin{array}{c}\text { w/cm } \\
\mathbf{\%}\end{array}$ & $\begin{array}{c}\text { SS } \\
\mathbf{\%}\end{array}$ & $\begin{array}{l}\text { Coir } \\
\text { fiber } \\
\mathbf{\%}\end{array}$ & $\begin{array}{l}\text { Hair } \\
\text { fiber } \\
\mathbf{\%}\end{array}$ & $\begin{array}{l}\text { PP } \\
\%\end{array}$ \\
\hline RF1 & 1 & 1.6 & 0.05 & 0.15 & 1.5 & 0.35 & 2 & - & - & - \\
\hline RF2 & 1 & 1.6 & 0.05 & 0.15 & 1.5 & 0.35 & - & 2 & - & - \\
\hline RF3 & 1 & 1.6 & 0.05 & 0.15 & 1.5 & 0.35 & - & - & 2 & - \\
\hline RF4 & 1 & 1.6 & 0.05 & 0.15 & 1.5 & 0.35 & - & - & - & 2 \\
\hline
\end{tabular}

\section{RESULTS}

\section{A. Cube Compression Test}

The following table shows the cube compressive strength of RPC and coir, sisal, polypropylene and hair fiber concrete at 7 and 28 days. The graphical representation compares the cube compressive strength of fiber concrete with the control concrete.

Table- IV: Cube Compressive Strength Test of FRRPC at 7 \& 28 days

\begin{tabular}{|l|l|l|}
\hline SPECIMEN & 7 DAYS & 28 DAYS \\
\hline Control & 128.91 & 184.16 \\
\hline Coir & 119.98 & 171.4 \\
\hline Sisal & 111.16 & 158.8 \\
\hline Polypropylene & 123.62 & 176.6 \\
\hline Hair & 100.24 & 143.2 \\
\hline
\end{tabular}

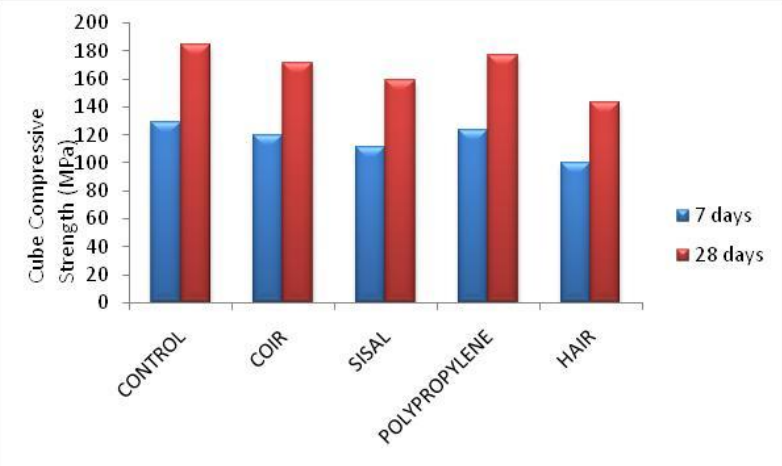

Fig. 3 Cube Compressive Strength of Fiber reinforced RPC after $7 \& 28$ days

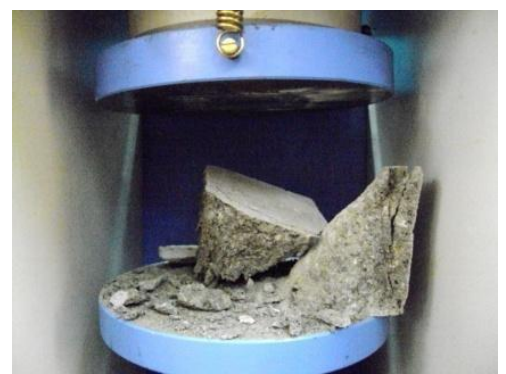

Fig. 4 Cube failure after testing

From the graph, we come to know that by incorporating fibers in RPC. The cube compressive strength reduces gradually because of the micro structural bonding affect.

\section{B. Cylindrical Compression Test}

The following table shows the cylinder compressive strength of RPC, coir, sisal, polypropylene and hair fiber concrete at 7 and 28 days. The graphical representation compares the cylinder compressive strength of fiber concrete with the control concrete.

Table- V: Cylindrical Compressive Strength Test of FRRPC at $7 \& 28$ days

\begin{tabular}{|l|l|l|}
\hline SPECIMEN & 7 DAYS & 28 DAYS \\
\hline Control & 96.8 & 138.8 \\
\hline Coir & 94.2 & 133.4 \\
\hline Sisal & 86.42 & 123.2 \\
\hline Polypropylene & 83.95 & 119.6 \\
\hline Hair & 84.6 & 121.1 \\
\hline
\end{tabular}

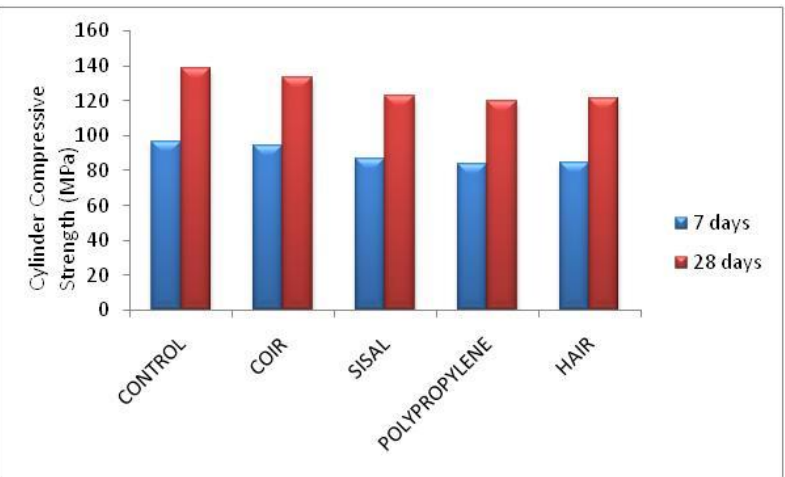

Fig. 5 Cylindrical Compressive Strength of Fiber reinforced RPC after $7 \& 28$

days

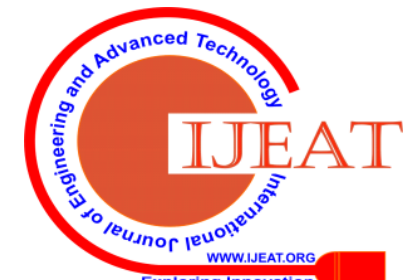




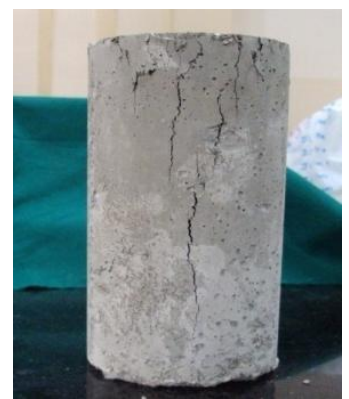

Fig. 6 Cylinder fails after testing

From the graph, we come to know that by incorporating fibers in RPC. The cylinder compressive strength reduces gradually because of the micro structural bonding affect.

\section{Split Tensile Test}

The following table shows the Split Tensile strength of RPC and coir sisal polypropylene and hair fiber concrete at 7 and 28 days. The graphical representation compares the Split Tensile strength of fiber concrete with the control concrete.

Table- VI: Splitting tensile Strength of Fiber reinforced RPC after $7 \& 28$ days

\begin{tabular}{|l|l|l|}
\hline SPECIMEN & 7 DAYS & 28 DAYS \\
\hline Control & 5.2 & 18.7 \\
\hline Coir & 8.5 & 25.6 \\
\hline Sisal & 7.9 & 22.3 \\
\hline Polypropylene & 9.2 & 28.9 \\
\hline Hair & 7.1 & 21.8 \\
\hline
\end{tabular}

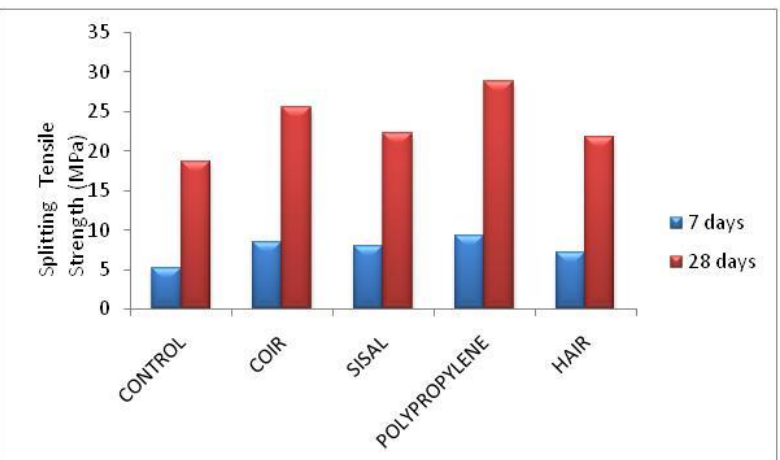

Fig. 7 Splitting tensile Strength of Fiber reinforced RPC after $7 \& 28$ days

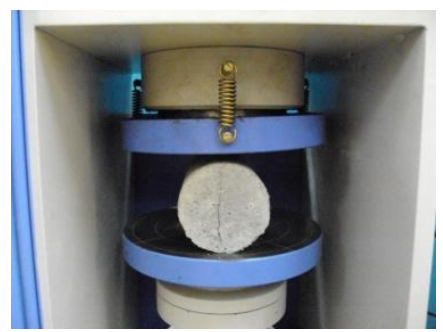

Fig. 8 Failure due to split tensile

From the graph, we come to know that while incorporating fiber in RPC. The splitting tensile strength can be increased. The RPC which was incorporating with Polypropylene fiber has the high strength with compare the other fiber concrete.

\section{Flexural Strength Test}

The following table shows the flexural strength of RPC and coir sisal polypropylene and hair fiber concrete at 7 and 28

days. The graphical representation compares the flexural strength of fiber concrete with the control concrete.

Table- VII: Flexural Strength of Fiber reinforced RPC after $7 \& 28$ days

\begin{tabular}{|l|l|l|}
\hline SPECIMEN & 7 DAYS & 28 DAYS \\
\hline Control & 6.1 & 19.9 \\
\hline Coir & 9.5 & 24.3 \\
\hline Sisal & 7.2 & 21.5 \\
\hline Polypropylene & 11.7 & 26.4 \\
\hline Hair & 5.9 & 19.2 \\
\hline
\end{tabular}

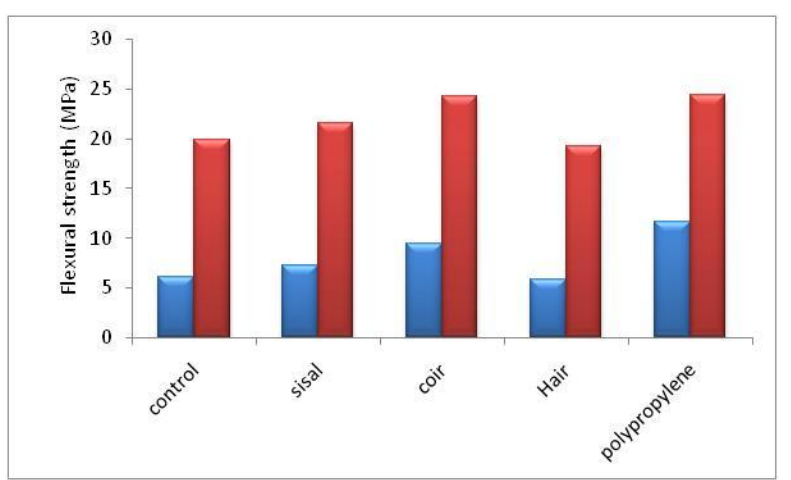

Fig. 9 Flexural Strength of Fiber reinforced RPC after 7 \& 28 days

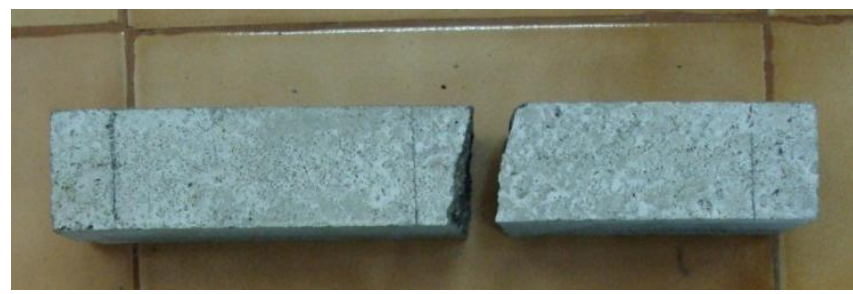

Fig. 10 Beam failure after testing

From the graph, we come to know that while incorporating fiber in RPC. The flexural strength can be increased. The RPC which was incorporating with Polypropylene fiber has the high strength with compare the other fiber concrete.

\section{E. Shear Strength Test}

The following table shows the shear strength of RPC and coir sisal polypropylene and hair fiber concrete at 7 and 28 days. The graphical representation compares the Shear strength of fiber concrete with the control concrete.

Table- VIII: Shear Strength of Fiber reinforced RPC after $7 \& 28$ days

\begin{tabular}{|l|l|l|}
\hline SPECIMEN & 7 DAYS & 28 DAYS \\
\hline Control & 11.4 & 36.9 \\
\hline Coir & 13.7 & 38.2 \\
\hline Sisal & 13.5 & 37.1 \\
\hline Polypropylene & 15.3 & 39.2 \\
\hline Hair & 14.6 & 38.4 \\
\hline
\end{tabular}

Published By:

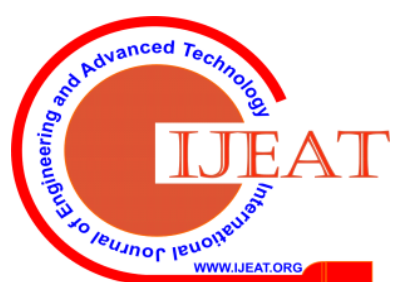
\& Sciences Publication 


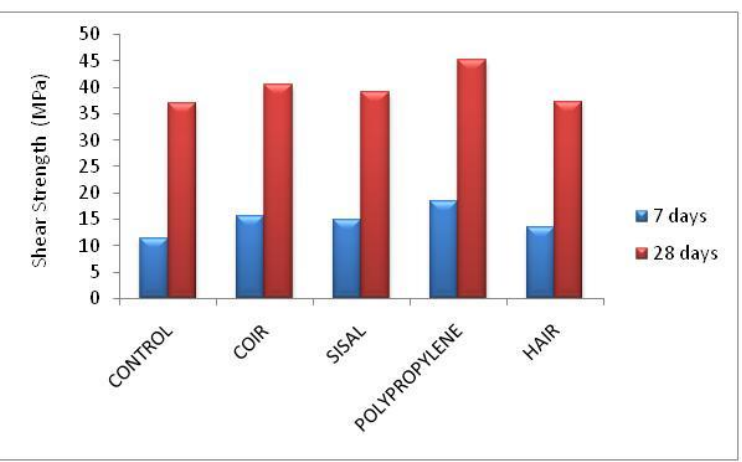

Fig. 11 Shear Strength of Fiber reinforced RPC after $7 \&$ 28 days

The following table shows the shear strength of RPC and coir sisal polypropylene and hair fiber concrete at 7 and 28 days. The graphical representation compares the Shear strength of fiber concrete with the control concrete.

\section{F. Impact Resistance Test}

The following table shows the Energy absorbed in RPC and coir sisal polypropylene and hair fiber concrete at 7 and 28 days. The graphical representation compares the Impact strength of fiber concrete with the control concrete.

Energy Absorbed = weight of steel ball X Height

Table- IX: Impact resistance Strength of Fiber reinforced RPC

\begin{tabular}{|l|l|l|l|}
\hline $\begin{array}{l}\text { Specimen } \\
\text { Designation }\end{array}$ & $\begin{array}{l}\text { Weight of } \\
\text { Steel ball } \\
(\mathrm{gm})\end{array}$ & $\begin{array}{l}\text { Height } \\
(\mathrm{mm})\end{array}$ & $\begin{array}{l}\text { Energy } \\
\text { Absorbed } \\
(\mathrm{kN} \mathrm{mm})\end{array}$ \\
\hline Control & 560 & 560 & 3.13 \\
\hline $\mathrm{S}$ & 560 & 630 & 3.5 \\
\hline $\mathrm{C}$ & 560 & 640 & 3.58 \\
\hline $\mathrm{H}$ & 560 & 590 & 3.3 \\
\hline $\mathrm{P}$ & 560 & 745 & 4.17 \\
\hline
\end{tabular}

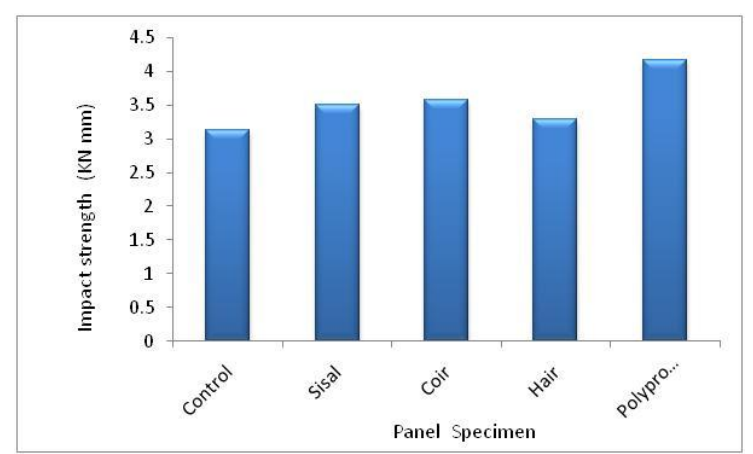

Fig. 12 Impact resistance Strength of Fiber reinforced RPC

\section{CONCLUSION}

Based on the Experimental investigation reported in this study, the following conclusions were drawn.

- The compressive strength of fiber reinforced reactive powder concrete decreased while incorporating the natural fibers. The compressive strength of Polypropylene fiber incorporated RPC decreases upto 5\%. But while incorporating hair fiber the compressive strength decreases upto $23 \%$ compared to normal RPC.
- The compressive strength of sisal fiber incorporated RPC decreases upto $14 \%$ and coir fiber incorporated RPC decreases upto $7 \%$ for 28 days.

- The splitting tensile strength of polypropylene fiber incorporated RPC has increased upto $55 \%$ for 28 days. But while incorporating the other fibers like sisal, coir and hair in RPC the splitting strength increases upto $37 \%$.

- The Flexural strength of polypropylene fiber incorporated RPC has increased upto $33 \%$ for 28 days. But while incorporating the other fibers like sisal, coir and hair in RPC the splitting strength increases upto $23 \%$.

- The shear strength of polypropylene fiber incorporated RPC has increased upto $6 \%$ for 28 days. But while incorporating the other fibers like sisal, coir and hair in RPC the splitting strength increases upto $4 \%$.

- The impact resistance of polypropylene fiber incorporated RPC has increased upto $33 \%$ for 28 days. But while incorporating the other fibers like sisal, coir and hair in RPC the splitting strength increases upto $15 \%$.

\section{REFERENCES}

1. O’Neil,E.F., Neeley, B.D and Cargile,J.D.(2001) “Tensile properties of very- high-strength Concrete for penetration-Resistant structures",US army Engineering Research and development center, May 2001.

2. Feylessoufi, A.,villieras,F.,Michot, L.J.,De donato, P.,cases, J.M.and Richard,P.(1996). "Water environment and nanostructural network in a reactive powder concrete." Cement and concrete composites 18, 23-29.

3. Aitcin.P.C. (1997), " the art and science of high-performance concrete." In: P.K. Mehta, Ed. Proceedings of Mario collepardi: symposium on advances in concrete science and technology, 8-10-1997, Rome, 107-126.

4. Dowd.W. (2000), "Reactive powder concrete[online]." Purdue university. available from: http://www.new-technologies.org/ECT/Civil/reactive [Accessed 11-09 $-2001]$

5. O’Neil,E.F. and Dowd,W.M.(1995). "Reactive powder concrete: Anew material for the construction industry." In:S.K. Ghosh, Ed.Third National concrete and Masonry Engineering conference, 15-17 june 1995.

6. Morin.V, Cohen-Tenoudji.F, Feylessoufi.A, Richard.P, " Evolution of the capillary network in a reactive powder concrete during hydration process", Cement and Concrete Research 32 (2002) 1907-1914.

7. Zain .M.F.M, Mahmudb.H.B, Ade Ilhama, Faizal.M, "Prediction of splitting tensile strength of high-performance concrete", Cement and Concrete Research 32 (2002) 1251-1258.

8. Guangcheng Long, Xinyou Wang, Youjun Xie, "Very-high-performance concrete with ultrafine powders", Cement and Concrete Research 32 (2002) 601-605.

9. Bayard.O, Ple.O, "Fracture mechanics of reactive powder concrete: material modelling and experimental investigations", Engineering Fracture Mechanics 70 (2003) 839-851.

10. Ramazan Demirbog, "Influence of mineral admixtures on thermal conductivity and compressive strength of mortar", Energy and Buildings 35 (2003) 189-192.

11. Wei Sun, Yunsheng Zhang, Sifeng Liu, Yanmei Zhang, "The influence of mineral admixtures on resistance to corrosion of steel bars in green high-performance concrete", Cement and Concrete Research 34 (2004) 1781-1785.

12. Yin-Wen Chan, Shu-Hsien Chu, "Effect of silica fume on steel fiber bond characteristics in reactive powder concrete", Cement and Concrete Research 34 (2004) 1167-1172.

13. Nabi Yuzer, Fevziye Akoz, Leyla Dokuzer o zturk, "Compressive strength-color change relation in mortars at high temperature", Cement and Concrete Research 34 (2004) 1803-1807.

14. Abouzar sadrekarimi, "Development of a light weight reactive powder concrete",Journal of advanced concrete technology (2004) Vol.2, No.3, 409-417. 
15. Dili.A.S, Manu Santhanam, “ Investigation on Reactive Powder Concrete: A Developing Ultra High-Strength Technology", The Indian Concrete Journal (2004), 33-38

16. Zhanga.M.H, Shimb.V.P.W, Lua.G, ChewaC.W., "Resistance of high-strength concrete to projectile impact",International Journal of Impact Engineering 31 (2005) 825-841.

17. Romildo D. Toledo Filho, Khosrow Ghavam, Miguel A. Sanjuán, George L. England, "Free, restrained and drying shrinkage of cement mortar composites reinforced with vegetable fibres", Cement \& Concrete Composites 27 (2005) 537-546.

18. Katrin Habel, Marco Viviani, Emmanuel Denarié, Eugen Brühwiler, "Development of the mechanical properties of an Ultra-High Performance Fiber Reinforced Concrete (UHPFRC)" ,Cement and Concrete Research 36 (2006) 1362-1370.

19. Ming-Gin Lee, Yung-Chih Wang, Chui-Te Chiu, “A preliminary study of reactive powder concrete as a new repair material", Construction and Building Materials 21 (2007) 182-189

20. Allan C.L. Wong ,Paul A. Childs, Richard Berndt, Tony Macken, Gang-Ding Peng, Nadarajah Gowripalan, "Simultaneous measurement of shrinkage and temperature of reactive powder concrete at early-age using fibre Bragg grating sensors", Cement \& Concrete Composites 29 (2007) 490-497

21. Patrick Stahli, Jan G.M. van Mier, "Manufacturing, fibre anisotropy and fracture of hybrid fibre concrete", Engineering Fracture Mechanics 74 (2007) 223-242

22. Zhang Yunsheng, Sun Wei, Liu Sifeng, Jiao Chujie, Lai Jianzhong, "Preparation of C200 green reactive powder concrete and its static-dynamic behaviors", Cement \& Concrete Composites 30 (2008) 831-838

23. Halit Yazıcı, Huseyin Yigiter, Anıl S_. Karabulut, Bulent Baradan, "Utilization of fly ash and ground granulated blast furnace slag as an alternative Silica source in reactive powder concrete", Fuel 87 (2008) 2401-2407

24. Cwirzen, Penttala.V, Vornanen.C, “ Reactive powder based concretes: Mechanical properties, durability and hybrid use with OPC", Cement and Concrete Research 38 (2008) 1217-1226.

25. Chin-Tsung Liu, Jong-Shin Huang, "Highly flowable reactive powder mortar as a repair material",Construction and Building Materials 22 (2008) 1043-1050.

26. Victor Y. Garas, Lawrence F. Kahn, Kimberly E. Kurtis, "Short-term tensile creep and shrinkage of ultra-high performance concrete", Cement \& Concrete Composites 31 (2009) 147-152

27. Burak Felekoglu, "A new approach to the characterisation of particle shape and surface properties of powders employed in concrete industry", Construction and Building Materials 23 (2009) 1154-1162

28. Chin-Tsung Liu, Jong-Shin Huang, "Fire performance of highly flowable reactive powder concrete", Construction and Building Materials 23 (2009) 2072-2079.

29. Halit Yazıcı, Mert Yucel Yardımcı, Serdar Aydın, Anıl S_. Karabulut, "Mechanical properties of reactive powder concrete containing mineral admixtures under different curing regimes", Construction and Building Materials 23 (2009) 1223-1231.

30. Zenati, Arroudj.K, Lanez.M, Oudjit.M.N, "Influence of cementitious additions on rheological and mechanical properties of reactive powder concretes", Physics Procedia 2 (2009) 1255-1261.

31. Richard, P. and Cheyreczy,M.H.(1994). "Reactive powder concretes with high ductility and 200-800 MPa Compressive strength." V.Mohan Malhotra symposium ACI SP -144, 21-23, March1994.

32. Richard, P. and Cheyrezy , M.H.(1995). "Composition of reactive powder concrete", Cement and concrete Research, 25(7), 1501-1511.

33. Philippot, s.,Masse,s.,Zanni,H., Nieto,P., Maret, V. and cherrezy,M.(1996). "Si NMR STUDY of hydration and Pozzolanic reactions in reactive powder concrete (RPC)", Magnetic resonance imaging, $14(7,8) 891-893$.

34. Neeley, B.d. and walley, D.M.(1995). "VHS concrete." The Military Engineer,87(572),36-37.

35. Bonneau,O.,Vernetb,C.,moranvillea,M. and Aitcin,P.(2000). "characterization of the granular packing and percolation threshold of the granular packing and percolation threshold of reactive powder concrete",cement and concrete research,30,1861-1867.

36. Cheyrezy,M.,Maret,V. and Frouin,L.(1995). "Micro structural analysis of RPC",cement and concrete Reseach,25 (7),1491-1500.

37. Adeline.R and behloul,M. (1996). "High ductile beams without passive reinforcement." in:F.delarrard and R.Lacroix, Eds. 4th international symposium on utilization of High -strength/ High Performance Concrete, Paris, France:29-31 may 1996.

38. Torrenti , J.M.,Matte,V.,Maret, V. and Richet ,C. (1996). "High integrity containers for interim storage of nuclear wastes using reactive power concrete."in:F.de Larrrard and R.Lacroix,Eds.4th international symposium on utilization of High- strength/High performance Concrete, Paris, France 29-31 May 1996.

39. Dauriac,c.(1997). "Special concrete may give steel stiff competition." the seattle daily journal of commerce, May 2001.

\section{AUTHORS PROFILE}

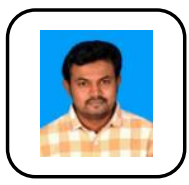

Mr. Arunkumar K is pursuing his $\mathrm{PhD}$ in Department of Civil Engineering from Kalasalingam Academy of Research and Education, Krishnankoil, India. He pursued his Bachelor degree in Civil Engineering from Sengunthar Engineering College, Tiruchengode, affiliated to Anna University, Chennai. Also, he pursued Master of Technology in Structural Engineering from Kalasalingam University, Krishnankoil. His areas of interests are Concrete Technology and Ferrocement Technology.

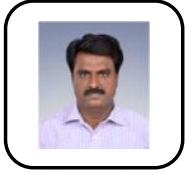

Dr.Muthukannan M completed his Ph.D in Civil Engineering in Anna University, Chennai in the year 2010. He completed Master of Engineering in the field of Transportation Engineering and Management in College of Engineering, Guindy, Chennai in the year 2004. He completed his Bachelor of Engineering under Madurai Kamarajar University in the year 2000. He is presently working as a Professor in Civil Engineering department at Kalasalingam University, Tamilnadu, India. He is guiding for many $\mathrm{Ph} . \mathrm{D}$ scholars in the field of transporation engineering and computer applications in transportation network using graph theory. He has published various quality papers in the reputed journals. His main thrust research areas are transportation network design, transport management and travel demand management.

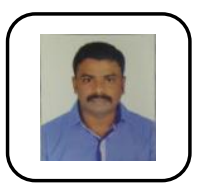

Mr. Suresh Kumar.A is pursuing PhD in Department of Civil Engineering from Kalasalingam Academy of Research and Education, Krishnankoil, India. He pursued his Bachelor degree in Civil Engineering from Raja College of Engineering and Technology, affiliated to Anna University, Chennai. Also, he pursued Master in Engineering in Structural Engineering from Mepco Schlenk Engineering College affiliated to Anna University, Thirunelveli. His areas of interests are Concrete Technology and Prestressed Concrete. 